Article

\title{
Linking Digital HRM Practices with HRM Effectiveness: The Moderate Role of HRM Capability Maturity from the Adaptive Structuration Perspective
}

\author{
Lijun Wang (D), Yu Zhou *(D) and Guoyang Zheng \\ Department of Organization and Human Resources, School of Business, Renmin University of China, \\ Beijing 100872, China; ljwang@ruc.edu.cn (L.W.); zhengguoyang@ruc.edu.cn (G.Z.) \\ * Correspondence: zhouyuhr@ruc.edu.cn; Tel.: +86-186-1116-4992
}

Citation: Wang, L.; Zhou, Y.; Zheng, G. Linking Digital HRM Practices with HRM Effectiveness: The Moderate Role of HRM Capability Maturity from the Adaptive Structuration Perspective. Sustainability 2022, 14, 1003. https:// doi.org/10.3390/su14021003

Academic Editor: Huseyin Arasli

Received: 28 December 2021

Accepted: 13 January 2022

Published: 17 January 2022

Publisher's Note: MDPI stays neutral with regard to jurisdictional claims in published maps and institutional affiliations.

Copyright: (C) 2022 by the authors. Licensee MDPI, Basel, Switzerland. This article is an open access article distributed under the terms and conditions of the Creative Commons Attribution (CC BY) license (https:// creativecommons.org/licenses/by/ $4.0 /)$.

\begin{abstract}
In recent years, increasing attention has been paid to digital human resource management (HRM) practices. Nonetheless, the impact of digital HRM practices is not yet fully understood by practitioners and researchers. Drawing from adaptive structuration theory (AST), we suggest that HRM capability maturity is a key boundary condition for understanding the effectiveness of digital HRM practices. By employing a path analysis approach on a sample of 1770 enterprises in China, this study found that the use of digital HRM practices impacts HRM effectiveness through the internal consistency of HR practices and external social networking of HR managers with line managers. The positive or negative effects of digital HRM practices depend on the enterprise's HRM capability maturity. While the majority of previous studies have explored the impact of digital HRM on organizations, including the effects on cost reduction and organizational performance, our study expanded the focus on the outcomes of digital HRM to include employees' perceptions of HRM effectiveness, which can further influence employees' attitudes and organizational behaviors. The implications of our findings for research and practice are discussed.
\end{abstract}

Keywords: adaptive structuration theory; digital HRM practices; HRM capability maturity; HR managers' social networking with line managers; internal consistency of HR practices; HRM effectiveness; China

\section{Introduction}

Digital human resource management (HRM) practices are "... the processes of employing digital technologies and appropriate data to promote the efficiency and effectiveness of HRM activities." [1] (p. 22) and have received increasing attention in recent years. For example, Google encourages the use of analytics for all HR functions. IBM's HR department has shifted almost the entirety of its functions, such as benefits enrollment, retirement planning, and online learning, to the digital platform. According to a survey conducted by Beisen Talent Management Institute, 22.2\% of Chinese organizations have practical experience in HR digitalization, and $70.6 \%$ of organizations are ready to incorporate digitalization into their HR processes [2]. A survey by Accenture revealed that $78 \%$ of Chinese executives believe that the rapid development of emerging technologies will, inevitably, shake their industries [3]. These, and related survey results, encourage researchers to focus on digital HRM practices. Scholars argue that digital HRM is an organizational capability that brings about positive effects through traditional statistics, sentiment analysis, or algorithms and are based on accumulated data [4]. Digital HRM has been shown to improve the quality of decision-making [5,6], help organizations adapt in a fast-paced environment in order to achieve competitive advantage [7], enhance HRM department strategy involvement [8,9], improve employee performance and experience [10], and further organizational financial performance [11,12]. 
Perhaps, however, the benefits of digital HRM are exaggerated. The impact of digital HRM practices is not yet fully understood by practitioners and researchers. There is a "productivity paradox" in practice [13]; many organizations, including large multinational organizations, have spent billions of dollars in support of digital HRM practices, but the financial benefits have not yet been realized [14,15]. Studies have also argued that e-HRM implementation has sometimes achieved less than expected outcomes [16]. For example, some studies have suggested that they did not find a significant relationship between e-HRM usage and cost reduction [17]. There are also some studies that argued that the use of HR analytics provides few benefits to organizations but damages the interests of employees [14].

Scholars explain that the varied or mixed results-some benefits and perhaps some drawbacks - may be due to implementation issues. HRM implementation is a dynamic process, beginning with the decision to adopt HRM practices, "during which relevant HRM actors (such as line managers, HR specialists, user employees) engage with it, interacting among themselves and attempting to shape it to fit their requirements and needs," until the HRM practice becomes routinized [18] (p. 155). Implementation effectiveness is considered an outcome of the implementation process. In view of the expected benefits of digital HRM, the important and relevant questions are: "When and why will digital HRM practices lead to positive results?" The when and why of these questions imply that specific boundary conditions affect digital HRM implementation and effectiveness.

Accordingly, the goal of this study is to examine when and why digital HRM promotes HRM effectiveness. HRM effectiveness can be explained by HRM system strength [19]. HRM system strength is an important construct in the field of human resource management. Whether an organization's HR practices are clearly perceived and recognized by employees and form a common belief and identity within them is an essential sign of the success of HRM [19]. However, there is still a relative lack of theoretical and empirical research on this important concept of HRM system strength. Employee perceptions of the distinctiveness, consistency, and consensus of HRM practices are used to measure the effectiveness of HRM. Specifically, distinctiveness refers to HRM systems that are highly observable; consistency is defined within an HRM system as one that presents itself evenly and dependably across modalities and time; and consensus refers to the agreement among employees' views of the HRM system [19]. In organizations, employees are the recipients of HRM practices; therefore, it is meaningful to understand their perceptions of HRM practices. Employees perceive and interpret HRM practices implemented by the organization in a particular manner, and these perceptions determine their attitude, behavior, and performance [20]. HRM system strength is an important outcome to consider in theoretical and practical research.

We address our earlier question by drawing upon adaptive structuration theory (AST), as "... it expounds the nature of social structures within advanced information technologies and the key interaction processes that figure in their use." [21] (p. 121). In accordance with AST theory, we propose that the effectiveness of digital HRM depends on the adoption of technology structures by organizational actors [21,22]. In particular, we suggest that digital HRM can lead to increased internal consistency in HR practices (i.e., complementarity among HR practices) by providing the structural features of digital technology. Structural features are "... the specific types of rules and resources, or capabilities, offered by the system." [21] (p. 126). Via digital technology and its spirit, i.e., "... the general intent with regard to values and goals underlying a given set of structural features" (p. 126), digital HRM can also promote social networking between HR managers and line managers (i.e., the opportunity to work seamlessly with colleagues across the company). HR department employees and line managers are the primary actors in HRM system implementation. The HR department secures and runs the HRM system at the organizational level, while the line managers implement it in each department. The HR department and line managers both influence the extent of HRM system implementation [23] as well as employee perception of the system [24]. 
Furthermore, we propose that the capability maturity of HRM moderates these mediating effects. AST theory suggests that the effectiveness of advanced information technology not only depends on the structure of the technology, but can also be influenced by other structures, such as internal context [21]. Existing studies have tended to examine the direct impact of digital HRM practices on organizations and individuals; we suggest that this focus on direct effect is faulty if intra-organizational context is not taken into account. In addition, existing studies exploring the requirements of digital HRM have focused on factors such as employee acceptance of the technology [25], HR professional analytical skills [26,27], or aiding managerial buy-in [28]. To date, very few empirical studies have been conducted on the maturity of HRM capability [1]. HRM capability maturity is defined as the maturity of an organization's workforce practices in managing and developing the workforce [29]. HRM capability maturity can be considered an intra-organizational context. Based on AST [21], we suggest that HRM capability maturity can act as both an opportunity and a constraint in the digital HR implementation process. A high level of HRM capability maturity not only represents a workforce with the ability to support strategic business plans, but also indicates that the organization is able to "... quantify the capability of its workforce and of the competency-based processes they use in performing their assignments." [29] (p. 26).

The effectiveness of advanced information technology within the organization and with employees may depend largely on the maturity of HRM capability; very high (or very low) HRM capability maturity may impact digital HRM practices [30]. We suggest that when HRM capability maturity is high, digital HRM practices make it easier to provide efficient services that meet the needs of line managers better, thereby promoting social networking between HR managers and line managers. The high maturity of the HRM system also helps realize the complementarity of functional HR practices. Together, these two processes promote employees' distinctiveness, consistency, and consensus perceptions of the HRM system, which further promotes HRM effectiveness. In summary, we suggest that digital HRM practices have an impact on HRM effectiveness through the internal consistency of HR practices and the external social networking of HR managers and line managers. The positive or negative effects of this impact depend on the maturity of the organization's HRM system (see Figure 1).

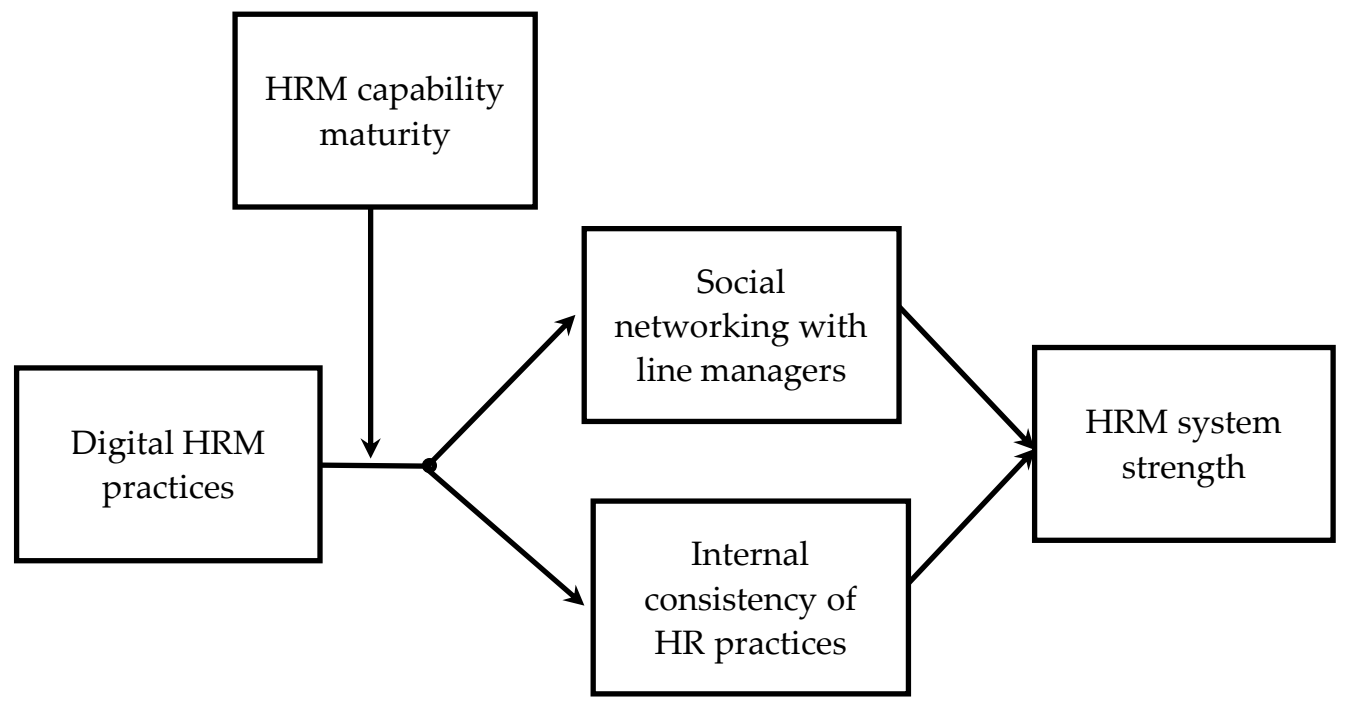

Figure 1. The theoretical model of the research.

This study makes several contributions. First, drawing on AST, we propose that the effectiveness of digital HRM is determined by the implementation process. Specifically, we demonstrate the interplay relationship of digital HRM practices and HRM capability maturity with action changes in organizations. Acknowledging the limited theoretical 
perspectives in digital HRM-related research [27,31], we have suggested that AST facilitates scholars' better understanding of the "productivity paradox" in practicing digital HRM. Second, by exploring HRM capability maturity as a key boundary condition of the effects of digital HRM, we challenge the prevailing consensus regarding the universally positive effects of digital HRM, providing an answer to the question of when digital HRM practices promote versus inhibit HRM effectiveness. Finally, we extend the digital HRM literature through examinations of the effect of two different mechanisms (internal consistency of HR practices and external social networking between HR managers and line managers) in mediating the relationship between digital HRM and HRM effectiveness. Examining the underlying mechanisms is of great importance, as it benefits building and testing organizational theory [32].

\section{Theoretical Grounding and Hypothesis Development}

AST theory provides a model that describes the interplay among advanced information technologies, social structures, and human interaction. Social structures, the basis for human activity, are the rules and resources that serve as templates for planning and accomplishing tasks. AST theory proposes that the “... major sources of structure for groups as they interact with an advanced information technology include the technology itself, the tasks, and the organizational environment." [21] (p. 128). AST offers a detailed account of both the structure of advanced technologies and the unfolding social interaction evidenced as the technologies are utilized. Specifically, the social structures provided by advanced information technology can be described in two ways: the structural features of the given technology and the spirit of this feature set. Use of advanced information technology may vary depending on the intra-organizational context, as technologies offer alternative sources of social structure. Hence, the effectiveness of digital HRM depends not only on the technology itself, but also on the intra-organizational context (the rules of action drawn from the organization) [21].

\subsection{The Interactive Effect of Digital HRM Practices and HRM Capability Maturity on HR Managers' Social Networking with Line Managers}

This section examines the impact of digital HRM practices and their joint impact with HRM capability maturity on HR managers' social networking with line managers. HR managers' social networking with line managers describes the extent to which HR managers interact with line managers.

According to AST theory, “... to the extent that advanced information technologies vary in their spirit and structural features sets, different forms of social interaction are encouraged by the technology." [21] (p. 128). The spirit is the "official line" that "... the technology presents to people regarding how to act when using the system, how to interpret its features." In terms of digital HRM, the spirit may reflect features, including features based on data evidence, which provide insight through analysis [27]. Digital technology is meant to encompass the spirit of seamless work with colleagues across the organization, overcoming the limits of human rationality to provide a more objective, accurate, and professional service. In this way, this spirit brings meaning and control to organization interaction. We suggest that digital HRM promotes HR's social networking with line managers by providing the spirit of digital technology, allowing for seamless work with colleagues across the organization.

We believe that digital HRM practices can improve HR managers' social networking with line managers for, at minimum, two reasons. First, digital HRM practices result in decisions based on data; digital HRM is an evidenced-based method to overcome the limits of human rationality and provide a more objective professional service. Furthermore, the more extensive use of digital HRM has enabled HR professionals to provide increased information responsiveness [33]. For example, answering queries faster and providing more accurate information [34]. Moreover, by increasing the connectivity of information, HR professionals can demonstrate flexibility in the face of unexpected changes [34]. The promotion 
of HR professionalization [35] and service quality [22,36], leading to augmented service satisfaction with the HR department [37] and satisfaction related to HR processes [38], are considered benefits of digital HRM. Digital HRM increases the HR department's service quality and promotes employee satisfaction with the department by laying the foundation for a good relationship with the line managers. Digital HRM also adds opportunities to make connections between HR managers and line managers. The value of using digital technology in HRM practices is illustrated by the promotion of communication and coordination among users. Once digital HRM is in place, other departments can learn more about what is happening in the organization, including the organization's newest and most comprehensive policies [39]. HR professionals can also access and analyze employee information readily. Without a digital system, HR personnel cannot easily analyze and solve problems in other departments. Briefly, digital HRM provides a relatively transparent and flexible pathway that can facilitate relationships. Previous studies have demonstrated that the adoption of digital HRM also facilitates interdepartmental connection, communication, and collaboration [38]. Digital HRM tools have increased the speed and ease of information sharing, and have streamlined HR processes [40,41].

Although digital HRM practices can improve HR managers' social networking with line managers, we believe that the maturity of HRM capability can also affect this relationship [17]. Workforce capability is considered a source of competitive advantage, but workforce capability must be adapted to the requirements of the organizations' strategic business objectives, "... because technologies ... evolve rapidly, organizations must continually evolve their workforce practices and develop new workforce competencies." [29] (p. 6). When HRM capability maturity level is high, digital HRM practices are able to use the results of quantitative management activities, and each employee's work processes can be integrated into an effective operating procedure for the workgroup. We posit that when digital HRM has a high level of HRM capability maturity, it can boost HR managers' social networking with line managers.

First, HRM capability maturity makes the connection between the HR managers and line managers more efficient and smoother during the implementation of the digital HRM practices. However, in low-maturity organizations, the lack of relevant knowledge or skills and poor communication are issues that can lead to workflow conflicts between line managers and the HR department. Using, as an example, the attendance data on a digital platform, the attendance of certain employees may appear to be problematic (late arrival and early departure). However, this attendance pattern may be determined by the nature of the employee's work (responsibilities that require the employee to leave the office). If the organization's HRM capability maturity does not match the capability of a digital HRM system, the line managers may have no effective channel to provide feedback to HR about emerging problems in real time, which, in turn, may lead to an inaccurate performance appraisal. However, digital HRM practices, supported by HRM capability maturity, allow managers to specify individual employee situations (for example, in a digital HRM system, managers would have the authority and access to change or note the specific attendance status of employees who need to leave the office). In such a system, the HR department can also obtain corrected attendance data in a timely manner based on the data or information communicated through input by line managers.

Second, the interactive effect of digital HRM and HRM capability maturity contributes to the quality of services provided by the digital HRM practices. For example, the interaction ensures that line managers are provided with the data they need to make decisions. Line managers make decisions referencing the data provided by digital HRM tools and can draw analytical conclusions that help them form judgments and improve the accuracy of their decisions. Otherwise, line managers may make decisions based on personal experience. The connection between line managers and HR managers can be strengthened through the data-sharing process when that data-sharing process is of high quality and reliability. 
The interaction between digital HRM and HRM capability maturity can also support the organization's strategy through quantitative data analysis. IT-supported HR applications have resulted in increased HR involvement in strategic roles [42]. Digital HRM processes can perform more targeted data collection and analysis to provide customized HRM support to business partners, and address the concerns of line managers, facilitating the relationship between HR managers and line managers.

In summary, when competent employees perform their tasks using proven competencybased processes, the line managers trust the results they produce. This helps other departments to faithfully adopt technology features and contributes to the perception that technology is valuable to them in their work. According to AST theory, the organization's decision process will vary depending on the nature of the advanced technology appropriations. Faithful adoption and a positive attitude will help HRM managers to build close relationships with line managers [21]. Previous empirical research has also argued that the maturity of HRM capability in the digital HRM practices benefits HRM service. For example, Ruël (2012) introduced AST theory into the e-HRM field. That study showed that the appropriation of e-HRM and its frequency of use were both positively related to HRM value creation [43]. Building on this finding, Bondarouk et al. (2017) used AST theory and empirically examined the relationship between e-HRM and HRM service quality; their study concluded that the key drivers of HRM service quality were the strengths of both HRM and e-HRM with the appropriation of e-HRM as a moderator [22].

Based on these arguments, we propose the following:

Hypothesis 1 (H1). Digital HRM and HRM capability maturity interact to influence HR managers' social networking with line managers such that the relationship is stronger when HRM capability maturity is high.

\subsection{HR Managers' Social Networking with Line Managers and HRM System Strength}

Further, we believe that HR managers' social networking with line managers triggered by digital HRM practices contributes to HRM system strength, which is determined by the distinctiveness, consistency, and consensus of the HR process [19]. In this study, we propose that the extent of HR managers' social networking with line managers influences the effect of digital HRM on HRM system strength for two reasons.

First, HR managers' social networking with line managers strengthens an HRM system by establishing distinctiveness. When digital HRM practices are strongly associated with line managers, the line managers may pay more attention to digital HRM. In this context, the digital HRM policies and practices will be understood and supported by the line managers; HRM practices, such as benefit plans or revenue-sharing plans, are then less likely to be misunderstood. Manager support has been reported to be essential for successful digital HRM implementation [44-48]. When HRM is supported by the line managers, employees are more likely to treat HRM as a credible benefit based on the influence and power of line managers. The involvement of key stakeholders (e.g., representatives from finance, operations, and marketing) also helps explain the logic of business [49]. A close relationship with the line managers allows HR managers to understand the current state of each business unit and employee demands better, thus facilitating and aligning employee goals with organizational goals. The distinctiveness of HRM is fostered by visibility, understandability, legitimacy of authority, and relevance [19], thus creating close social networking between HR managers and line managers.

Second, HR managers' social networking with line managers also builds consistency and consensus, contributing to robust HRM system strength. The HRM personnel and line managers both influence the employees' understanding of the cause-effect relationship between behavior and outcomes [19]. When HR managers and line managers enjoy close relationships, they are likely to form a common cognitive base [1]. This relationship may lead to a more consistent perceived cause-effect relationship and generate consensus among the employees. Employees also build consensus by perceiving the fairness of the HRM 
practices, owing to the close relationships between their department heads and the HR staff. This deepens the employees' understanding of HR policies around compensation and other topics.

Combining these arguments on the power and influence of social networking on digital HRM system strength with the interactive impact of digital HRM and HRM capability maturity on HR managers' social networking with line managers, we propose our second hypothesis:

Hypothesis 2 (H2). HR managers' social networking with line managers mediates the interactive effect of digital HRM and HRM capability maturity on HRM system strength such that the indirect effect is stronger when HRM capability maturity is high.

\subsection{The Interactive Effect of Digital HRM Practices and HRM Capability Maturity on the Internal Consistency of HR Practices}

We suggest that digital HRM can also increase the internal consistency of HRM practices, especially if the organization has a high HRM capability maturity.

Drawing on AST theory, the different structural features of technology encourage different forms of social interaction. Digital HRM may reflect features such as interactions in the information system or instant feedback [50]. In this way, technology can bring meaning and control to organization interaction.

We believe that digital HRM practices can promote the internal consistency of HR practices for the following specific reasons. First, the interactive technology feature of digital HRM provides a basis for connecting the practices related to HR functions. With a digital HRM platform, various HR practices can be linked more closely. For example, in a company with multiple branches, when management is moved to a digital platform, the head office is able to understand the HR practices of each branch and develop integrated solutions to address problems that may arise [51]. Within the same organization, data from each branch's HR practices can be collected effectively, facilitating information-sharing and promoting mutual understanding, connection, and cooperation. Second, digital HRM practices include many HRM functions, including compensation, recruiting, training, and human resource planning [52,53]. Organizations can utilize data accumulation and analysis strategies already established in the digital system to help coordinate the various HR modules. For example, the data analytics technology of the digital platform can help organizations evaluate high-performing employees, expand and refine recruitment based on high-performance employee characteristics, match corresponding salaries, and provide training to employees with poor performances. This coordination increases the overall effect beyond the sum of each individual HR functional practice. Previous research has also concluded that digital HRM practices can coordinate HR activities [54,55].

Although we assert that digital HRM practices can lead to higher internal consistency in HR practices, HRM capability maturity may affect this relation, as the level of HRM capability maturity impacts the operation of the digital HRM practices. Internal consistency of HR practices refers to the complementarity among overall HR functions [56]. Complementarity requires mutually supportive systems so that the "whole" of HRM practices is more effective than the sum of its individual HR functions [57]. We posit that when digital HRM has a high HRM capability maturity, it can boost the internal consistency of HR practices for, at minimum, the following three reasons:

First, having developed HRM capability maturity, the organization has established a systematic HRM process that matches each HR functional practice. There are uniform rules about what data to collect and what indicators to focus on. The implementation process for digital HRM practices is a cycle of operations, data generation, machine learning, and decision-making [58]. Without a standardized process, individual departments may use different metrics to measure the same indicator (e.g., performance), which would result in inconsistent data collection and therefore the inability to achieve internal consistency and alignment. 
Second, HRM capability maturity can ensure that employees act in accordance with organizational rules. When digital HRM is implemented, some HR employees, especially those who have extensive work experience and are familiar with the specific responsibilities of each HR function, may be resistant to the changes that the new system will bring to their work [59]. In this case, even if digital HRM practices are adopted, they may not be effective without the accommodation of HRM capability. For example, if employees do not use the digital system, there is no way to build information-sharing into HRM functional practices.

Additionally, the digital HRM system is developed uniformly and may not be suitable for every organization. In order to strengthen the connection of each HR functional practice and promote the cooperation of each module, the organization itself should have a corresponding supporting HRM capability. Consider the performance and compensation platform of Uber as an example; the algorithm behind the platform represents the organization's HRM system rules. The rules direct the platform to collect specific driver data for performance evaluations and ratings and as a criterion for compensation. Based on continuous accumulation and quantitative analysis of the data, the platform's HRM processes are also iterated and upgraded, therefore creating high-quality internal consistency for the company's HR practices. In contrast, without maturity and the appropriation of HRM processes, digital HRM practices cannot operate effectively and may not be able to exploit fully the efficacy of digital HRM, potentially creating confusion [40,60]. In summary, we posit that when digital HRM has a high HRM capability maturity, it can help the digital HRM's technological structure and intra-organizational structures to be better combined, and for instrumental use. According to AST theory, a better appropriation nature helps to promote the internal consistency of HR practices [21].

Based on these arguments, we propose the following hypothesis:

Hypothesis 3 (H3). Digital HRM and HRM capability maturity interact to influence the internal consistency of HR practices such that the relationship is stronger when HRM capability maturity is high.

\subsection{Internal Consistency of HR Practices and HRM System Strength}

We suggest that the internal consistency of HR practices due to the interaction between digital HRM and HRM capability maturity increases HRM system strength.

Internal consistency of HR practices contributes to HR system strength for the following three reasons. First, it is easier for employees to understand the cause-effect relationship between behavior and results based on the internal consistency of HR practices, thus promoting the distinctiveness of the HRM system [19]. One of the major advantages of digital HRM practices is their visibility. Measures, including those for performance and compensation management, are more transparent. In addition, the internal consistency of HR practices based on digital practices increases HRM system strength by establishing visibility.

Second, the cooperation of each HR functional practice helps employees feel the stability of the HRM system. Returning to the Uber platform example, through algorithms for evaluation, rating, compensation, and other interrelated HRM practices, driver working time, service attitude and subsequent compensation, rating, and other results are closely linked and managed consistently.

Third, the adaptability and complementarity of the HR department conveys consistent HRM messages to employees. For example, if HR practices have internal consistency, HRM may be able to focus on teamwork when hiring if performance evaluations reveal that teamwork is critical to improving team performance. In terms of compensation, the organization may motivate employees through team performance rather than individual performance. These are just a few examples of providing consistent HRM messaging to employees, messages that further promote agreement in the employees' views of the HRM system.

HR practices within digital HRM exhibit complementary interdependencies. Reliance on any single function alone may not be sufficient to create a consistent perception of the 
HRM system and trigger the desired employee outcomes [61,62]. Previous studies have also demonstrated that the internal consistency of HR practices is one of the most critical and relevant factors that can increase employee HRM strength [63].

Based on these arguments and the impact of digital HRM and HRM capability maturity on the internal consistency of HR practices, we propose the following hypothesis:

Hypothesis 4 (H4). The internal consistency of HR practices mediates the interactive effect of digital HRM and HRM capability maturity on HRM system strength such that the indirect effect is stronger when HRM capability maturity is high.

\section{Method}

\subsection{Participants and Procedures}

This study was conducted using an online survey in conjunction with the largest "software as a service" company in China: Beisen. We collected data through a professional questionnaire platform (https: / / www.wenjuan.com/accessedon, 24 November 2019). Employees working in enterprises, especially those from HR departments, were invited to respond to the questionnaire. The online questionnaire asked employees to evaluate their companies' digital HRM practices, HRM capability maturity, HR managers' social networking with line managers, internal consistency of HR practices, and perceived HRM system strength, based on their actual work experience. We also asked respondents to provide basic information about the company, such as the company's size and age. All participants received a cash reward after completing the questionnaire.

A total of 2582 questionnaires were collected. Due to the openness of the questionnaire platform, we selected valid questionnaires based on the following three criteria. First, a questionnaire that took longer than five minutes to complete was valid; otherwise, it was considered invalid. Second, a questionnaire was considered invalid if the respondent selected the same response option continuously across multiple items. Third, comprehensive judgement based on completion of fill-in-the-blank questions (e.g., enterprise name, name of respondent, etc.). There were 1770 valid questionnaires (68.55\%). Of all the employee respondents, female and male respondents accounted for $52.8 \%$ and $47.2 \%$, respectively. The average age of the respondents was 30.87 years $(\mathrm{SD}=5.99) ; 78.7 \%$. of the respondents had an educational level of a bachelor's degree or above.

\subsection{Measures}

\subsubsection{Digital HRM Practices}

We adapted a 33-item high performance work system measurement tool from Patel et al. (2013) to measure the companies' digital HRM practices [64]. A 5-degree Likert-type scale was used ( $1=$ strongly disagree to $5=$ strongly agree). Sample items included "The duties in this job are clearly defined on a digital system" and "There are formal training programs, including digital tools such as e-learning systems, which teach new hires the skills they needed for their jobs." The Cronbach's alpha for this study and its scale was 0.93 .

\subsubsection{HRM Capability Maturity}

Based on the Capability Maturity Model proposed by Mellon University [29], this study used a relatively simple approach for measuring HRM capability maturity, employing just one survey item. Based on the interviews conducted before the online survey was offered, we developed five statements in progressive order as the five possible responses to the survey question. The employees were asked to choose one of the five responses to evaluate the HRM capability maturity of their company based on the company's actual situation. Before data analysis, we converted these response options to numbers 1-5; as a sample, one of the options was: "The company has established a standardized and systemically matched HRM system." 


\subsubsection{HR Managers' Social Networking with Line Managers}

We used the closeness of the social network to represent the HR managers' social networking with line managers. The study's primary focus was the dual mediating role of the external (line managers) and internal (HR functional practices) institutional relationship between digital HRM and HRM effectiveness facilitated by digital HRM. In our model, the internal consistency of HR functional practices was reflected in the close relationships among the various internal HR functional practices. In parallel to this consideration was the external network connecting the HR staff and line managers. The study chose to focus on the degree of closeness of the relationship between the HR personnel and employees in different departments. The first question about the HR managers' social networking with line managers inquired about the number of employees who contact the HR department, a number that reflects the size of the company's HR network. The second question, pertaining to how many times per week the HR manager communicated with line managers, reflected the frequency of communication. Frequency may facilitate cooperation between the HR managers and line managers but is not a direct indicator of the degree of the relationship. Moreover, communication frequency may be based on business needs, or the HR department may be in frequent and extensive communication with everyone in the company. This questionnaire item did not represent the degree of cooperation and intimacy. The third question focused on closeness, a measure designed to capture accurately the degree of cooperation and intimacy between the interactions; this information was directly in line with the study's aim and our theory premise. Following Kim, Su, and Wright (2018), the closeness of the social network was measured by asking "How close do you feel when you discuss questions with department-level line managers?" $(1=$ not at all close, $5=$ very close) [65].

\subsubsection{Internal Consistency of HR Practices}

Partly referring to previous studies [56,57], we measured the internal consistency of HR practices using one survey item. Based on the pre-survey interviews, we developed six statements in progressive order to act as the six possible responses to this item. Based on the company's true current situation, the employees were asked to choose one of the six responses to evaluate the internal consistency of HR practices. Before data analysis, we converted these response options to numbers 1-6; one of the possible responses was: "The HR department sets up several basic function modules, each module is relatively independent, and the work or personnel coordination is assigned by HR leaders primarily."

\subsubsection{HRM System Strength}

HR system strength was measured by a 7-item scale developed by Hauff et al. (2017) [66]; a 5-degree Likert-type scale was employed for responses $(1=$ strongly disagree to $5=$ strongly agree). Sample items included "HR personnel and executive managers follow the same guidelines in implementing HRM" and "We realize the effects we intend to achieve with our HR practices." The Cronbach's alpha for this scale was 0.91 .

\subsubsection{Control Variables}

The study controlled for three variables: firm age, size, and ownership type. As previous HRM research has indicated that the firm size is positively related to HRM effectiveness [42]), the present study controlled for firm size, which was measured as the total number of employees in the company and summarized on a 6-point ordinal scale from 1 (99 or less) to 6 (10,000 or more). Five dummy variables were created. Consistent with existing research, we controlled for firm ownership type (state-owned enterprise [SOE], private, joint venture, foreign venture, and others); four dummy variables were created.

For scales that did not yet have Chinese versions, we followed Brislin's (1970) backtranslation translation procedure to translate all English scales into Mandarin Chinese [67]. 


\section{Results}

Hypothesis Testing

Table 1 presents the means, standard deviations, correlations of variables, and reliabilities of focal variables. As shown in Table 1, digital HRM practices were positively correlated with HR managers' social networking with line managers $(\mathrm{r}=0.24, p<0.01)$, internal consistency of HR practices $(\mathrm{r}=0.17, p<0.01)$, and HRM system strength $(\mathrm{r}=0.71$, $p<0.01)$. HR managers' social networking with line managers $(\mathrm{r}=0.36, p<0.01)$ and internal consistency of HR practices $(r=0.20, p<0.01)$ were positively correlated with HRM system strength.

We used Harman's single factor test to evaluate the common method variance. The result of the exploratory factor analysis showed that the first factor explains $48.57 \%$ of the variance, which indicated that the common methods bias does not affect the validity of our results [68].

The results of CFAs showed in Table 2 demonstrated that our hypothesized five factor model $\left(c^{2}=2665.70, d f=929, \mathrm{CFI}=0.96\right.$, TLI $\left.=0.96, \mathrm{RMSEA}=0.03, \mathrm{SRMR}=0.02\right)$ fit the data better than the alternative four-factor model $\left(\Delta c^{2}=69.63, \Delta d f=3\right)$, three-factor model $\left(\Delta c^{2}=491.20, \Delta d f=6\right)$, or two-factor model $\left(\Delta c^{2}=491.56, \Delta d f=7\right)$.

We employed a path analysis approach using Mplus 7.4 to test the study's hypotheses. As demonstrated in Table 3, the digital HRM practices were positively correlated with the HR managers' social networking with line managers $(\beta=0.34, p<0.001$, $95 \% \mathrm{CI}=[0.26,0.40])$, and positively correlated with the internal consistency of HR practices $(\beta=0.31, p<0.001,95 \% \mathrm{CI}=[0.22,0.40])$. Hypothesis 1 proposed that HRM capability maturity moderates the relationship between digital HRM practices and HR managers' social networking with line managers. As shown in Table 3, the interaction of digital HRM practices and HRM capability maturity had a positive effect on the HR managers' social networking with line managers $(\beta=0.08, p<0.05,95 \% \mathrm{CI}=[0.01,0.14])$. As presented in Figure 2, the simple slope tests confirmed that the relationship between digital HRM and the HR managers' social networking with line managers was significant and positive when HR system maturity was high $(\beta=0.43, p<0.001,95 \% \mathrm{CI}=[0.32,0.54])$, and was also significant and positive when HR system maturity was low $(\beta=0.24, p<0.001$, $95 \% \mathrm{CI}=[0.12,0.34])$. Furthermore, the simple slope difference between the high and low levels of HR system maturity was also significant (diff $=0.20, p<0.05,95 \% \mathrm{CI}=[0.03,0.40]$ ). Thus, Hypothesis 1 was supported.

Hypothesis 2 proposed that HRM capability maturity moderates the indirect relationship between the digital HRM practices and HRM system strength via the HR managers' social networking with line managers. As demonstrated in Table 4, the indirect effect of digital HRM on HRM system strength via HR managers' social networking with line managers was significant when HRM capability maturity was high $(\beta=0.05, p<0.001$, $95 \% \mathrm{CI}=[0.03,0.07])$; the indirect effect of digital HRM on HRM system strength via HR managers' social networking with line managers was also significant when HRM capability maturity was low $(\beta=0.02, p<0.01,95 \% \mathrm{CI}=[0.01,0.04])$. The difference between these indirect effects was also significant (diff $=0.02, p<0.05,95 \% \mathrm{CI}=[0.01,0.04]$ ), thus supporting Hypothesis 2.

Hypothesis 3 proposed that HRM capability maturity moderates the relationship between digital HRM practices and the internal consistency of HR practices. As demonstrated in Table 3, the interaction of the digital HRM practices and HRM capability maturity had a positive effect on the internal consistency of HR practices $(\beta=0.15$, $p<0.01,95 \% \mathrm{CI}=[0.06,0.23])$. As presented in Figure 3, the simple slope tests confirmed that the relationship between digital HRM and the internal consistency of HR practices was significant and positive when HR system maturity was high $(\beta=0.50, p<0.001$, $95 \% \mathrm{CI}=[0.34,0.65])$ and was insignificant when HR system maturity was low $(\beta=0.11$, n.s., $95 \% \mathrm{CI}=[-0.03,0.26])$. The difference of the simple slope between the high and low levels of HR system maturity was also significant ( $\operatorname{diff}=0.39, p<0.01,95 \% \mathrm{CI}=[0.16,0.62]$ ). Thus, Hypothesis 3 was supported. 
Table 1. Means, Standard Deviations, and Correlations.

\begin{tabular}{|c|c|c|c|c|c|c|c|c|c|c|c|c|c|c|c|c|c|}
\hline & & $\mathbf{M}$ & SD & 1 & 2 & 3 & 4 & 5 & 6 & 7 & 8 & 9 & 10 & 11 & 12 & 13 & 14 \\
\hline 1. Organization Age & 15.64 & 17.35 & & & & & & & & & & & & & & & \\
\hline 2.Organization Dummy 1 & 0.15 & 0.36 & $0.15^{* *}$ & & & & & & & & & & & & & & \\
\hline 3. Organization Dummy 2 & 0.38 & 0.49 & 0.10 ** & $0.34^{* *}$ & & & & & & & & & & & & & \\
\hline 4. Organization Dummy 3 & 0.27 & 0.45 & 0.01 & 0.26 ** & $0.49 * *$ & & & & & & & & & & & & \\
\hline 5. Organization Dummy 4 & 0.14 & 0.35 & 0.00 & $0.17^{* *}$ & $0.32 * *$ & $0.25 * *$ & & & & & & & & & & & \\
\hline 6. Organization Dummy 5 & 0.12 & 0.33 & $0.15^{* *}$ & $0.06^{*}$ & $0.20 * *$ & $0.10^{* *}$ & $0.11 * *$ & & & & & & & & & & \\
\hline 7. Organization Dummy 6 & 0.31 & 0.46 & 0.11 ** & 0.05 & $0.15 * *$ & $0.05 *$ & 0.09 ** & $0.25 * *$ & & & & & & & & & \\
\hline 8. Organization Dummy 7 & 0.30 & 0.46 & 0.04 & 0.01 & $0.15 * *$ & $0.15 * *$ & $0.06^{*}$ & $0.25 * *$ & $0.44 * *$ & & & & & & & & \\
\hline 9. Organization Dummy 8 & 0.19 & 0.39 & $0.09 * *$ & 0.03 & $0.14 * *$ & 0.02 & 0.12 ** & $0.18 * *$ & $0.33 * *$ & $0.32 * *$ & & & & & & & \\
\hline $\begin{array}{l}\text { 11. HR managers' social networking with } \\
\text { line managers }\end{array}$ & 3.66 & 0.87 & 0.04 & 0.03 & $0.06^{* *}$ & 0.01 & 0.03 & $0.11 * *$ & 0.02 & 0.05 & $0.05 *$ & $0.24^{* *}$ & & & & & \\
\hline 12. Internal consistency of HR practices & 3.46 & 1.22 & 0.01 & 0.03 & 0.02 & 0.00 & 0.05 & $0.07^{* *}$ & 0.04 & 0.00 & 0.02 & $0.17^{* *}$ & $0.21 * *$ & & & & \\
\hline 13. HRM capability maturity & 2.66 & 1.14 & 0.03 & 0.00 & 0.00 & 0.01 & 0.01 & 0.02 & 0.03 & 0.01 & 0.03 & $0.11 * *$ & $0.16^{* *}$ & $0.24 * *$ & & & \\
\hline 14. HRM system strength & 3.95 & 0.77 & 0.03 & $0.08^{*}$ & 0.02 & 0.02 & $0.07^{* *}$ & $0.05^{*}$ & 0.04 & $0.06^{*}$ & $0.06^{*}$ & $0.71 * *$ & $0.36 * *$ & $0.20^{* *}$ & $0.13^{* *}$ & & 0.91 \\
\hline
\end{tabular}

Note: $N=1770$. Reliabilities are listed in parentheses. Numbers in the parentheses are coefficient alpha. ${ }^{*} p<0.05,{ }^{* *} p<0.01$. 
Table 2. Model fit results for confirmatory factor analyses.

\begin{tabular}{ccccccc}
\hline Model & $\mathbf{c}^{\mathbf{2}}(\boldsymbol{d} \boldsymbol{f})$ & CFI & TLI & RMSEA & $\Delta \mathbf{c}^{\mathbf{2}}(\boldsymbol{\Delta d f})$ & SRMR \\
\hline Five-factor model & $2665.70(929)$ & 0.96 & 0.96 & 0.03 & 0.02 & $69.63(3)$ \\
Four-factor model & $2735.33(932)$ & 0.96 & 0.96 & 0.03 & 0.03 \\
Three-factor model & $3156.90(935)$ & 0.95 & 0.95 & 0.04 & $491.20(6)$ & 0.03 \\
Two-factor model & $3157.26(936)$ & 0.95 & 0.95 & 0.04 & $491.56(7)$ & 0.03 \\
\hline
\end{tabular}

Note: Five-factor model $=$ the hypothesized model. Four-factor model $=$ combined social networking with line manager and internal consistency of HR practices. Three-factor model $=$ combined social networking with line manager, internal consistency of HR practices, and HRM system strength. Two-factor model = combined social networking with line manager, internal consistency of HR practices, HRM system strength, and HRM capability maturity.

Table 3. Path analysis of the direct and interactive effects.

\begin{tabular}{|c|c|c|c|c|c|c|c|c|c|}
\hline \multirow{2}{*}{ Relationships } & \multicolumn{3}{|c|}{$\begin{array}{c}\text { Social Networking with Line } \\
\text { Managers }\end{array}$} & \multicolumn{3}{|c|}{$\begin{array}{c}\text { Internal Consistency of HR } \\
\text { Practices }\end{array}$} & \multicolumn{3}{|c|}{ HRM System Strength } \\
\hline & B & $S E$ & $95 \% \mathrm{CI}$ & $B$ & $S E$ & $95 \%$ CI & $B$ & $S E$ & $95 \%$ CI \\
\hline \multicolumn{10}{|l|}{ Direct Effect } \\
\hline Organization Age & $0.00 *$ & 0.00 & {$[0.00,0.00]$} & $0.00 *$ & 0.00 & {$[0.01,0.00]$} & 0.00 & 0.00 & {$[0.00,0.00]$} \\
\hline Organization Dummy 1 & 0.16 & 0.11 & {$[0.37,0.05]$} & 0.30 & 0.17 & {$[0.02,0.63]$} & 0.03 & 0.08 & {$[0.12,0.20]$} \\
\hline Organization Dummy 2 & 0.20 & 0.11 & {$[0.41,0.00]$} & 0.29 & 0.15 & {$[0.01,0.59]$} & 0.04 & 0.08 & {$[0.20,0.12]$} \\
\hline Organization Dummy 3 & 0.18 & 0.11 & {$[0.38,0.04]$} & 0.23 & 0.16 & {$[0.07,0.55]$} & 0.05 & 0.08 & {$[0.20,0.12]$} \\
\hline Organization Dummy 4 & 0.10 & 0.12 & {$[0.33,0.13]$} & 0.12 & 0.17 & {$[0.21,0.43]$} & 0.09 & 0.08 & {$[0.25,0.06]$} \\
\hline Organization Dummy 5 & $0.31^{* *}$ & 0.10 & {$[0.51,0.11]$} & $0.50 * * *$ & 0.14 & {$[0.80,0.22]$} & 0.02 & 0.07 & {$[0.14,0.12]$} \\
\hline Organization Dummy 6 & 0.12 & 0.09 & {$[0.30,0.05]$} & 0.23 & 0.13 & {$[0.47,0.02]$} & 0.05 & 0.06 & {$[0.06,0.17]$} \\
\hline Organization Dummy 7 & 0.05 & 0.09 & {$[0.23,0.12]$} & $0.28 *$ & 0.13 & {$[0.52,0.03]$} & 0.03 & 0.05 & {$[0.07,0.14]$} \\
\hline Organization Dummy 8 & 0.01 & 0.09 & {$[0.19,0.18]$} & $0.27 *$ & 0.13 & {$[0.52,0.01]$} & 0.04 & 0.06 & {$[0.15,0.08]$} \\
\hline $\begin{array}{l}\text { Digital HRM practices } \\
\text { HR managers' social }\end{array}$ & $0.34^{* * *}$ & 0.04 & {$[0.26,0.40]$} & $0.31^{* * *}$ & 0.05 & {$[0.22,0.40]$} & $0.81^{* * *}$ & 0.03 & {$[0.75,0.86]$} \\
\hline $\begin{array}{l}\text { net-working with line } \\
\text { managers }\end{array}$ & & & & & & & $0.10^{* * *}$ & 0.02 & {$[0.07,0.14]$} \\
\hline $\begin{array}{l}\text { Internal consistency of HR } \\
\text { practices }\end{array}$ & & & & & & & $0.03 * *$ & 0.01 & {$[0.01,0.06]$} \\
\hline Interactive effect & & & & & & & & & \\
\hline HRM capability maturity & $0.06^{* * *}$ & 0.02 & {$[0.03,0.10]$} & $0.22 * * *$ & 0.03 & {$[0.17,0.27]$} & 0.02 & 0.01 & {$[0.00,0.04]$} \\
\hline $\begin{array}{l}\text { Digital HRM practices } \\
\text { HRM capability maturity }\end{array}$ & $0.08 *$ & 0.03 & {$[0.01,0.14]$} & $0.15^{* *}$ & 0.04 & {$[0.06,0.23]$} & 0.00 & 0.02 & {$[0.04,0.05]$} \\
\hline
\end{tabular}

Note: Unstandardized path coefficients $p<0.05\left(^{*}\right), p<0.01\left(^{* *}\right), p<0.001\left(^{(* * *)}\right.$.

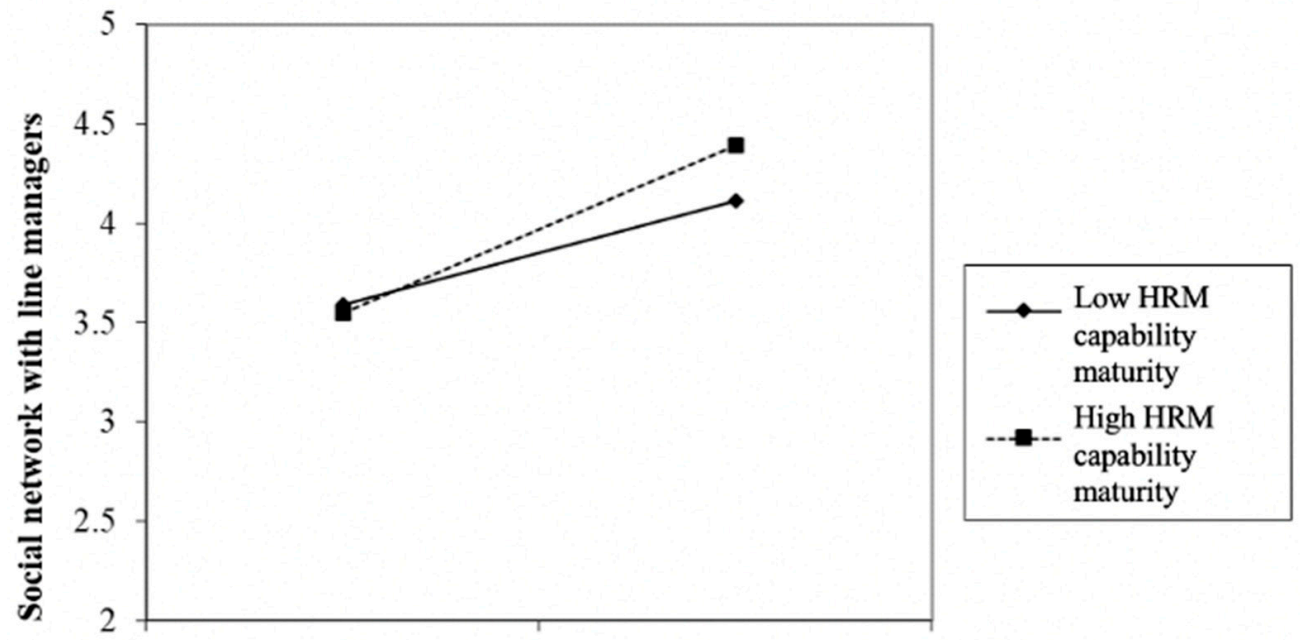

Low Digital HRM High Digital HRM

Figure 2. Interaction effect between digital HRM and HRM system maturity on social networking with line managers. 
Table 4. Results of indirect and mediated moderation effect.

\begin{tabular}{|c|c|c|c|c|}
\hline \multirow[t]{2}{*}{ Relationships } & \multicolumn{2}{|c|}{$\begin{array}{l}\text { (DHRM } \rightarrow \text { Social Networking with Line } \\
\text { Managers } \rightarrow \text { HRM System Strength) }\end{array}$} & \multicolumn{2}{|c|}{$\begin{array}{c}\text { (DHRM } \rightarrow \text { Internal Consistency of HR } \\
\text { Practices } \rightarrow \text { HRM System Strength) }\end{array}$} \\
\hline & $B$ & $95 \% \mathrm{CI}$ & $B$ & $95 \% \mathrm{CI}$ \\
\hline Indirect relationship & $0.04^{* * *}$ & {$[0.02,0.05]$} & $0.01 *$ & {$[0.00,0.02]$} \\
\hline Conditional indirect relationships & & & & \\
\hline High HRM capability maturity (+1SD) & $0.05^{* * *}$ & {$[0.03,0.07]$} & $0.02 *$ & {$[0.01,0.03]$} \\
\hline Low HRM capability maturity ( $-1 \mathrm{SD})$ & $0.02 * *$ & {$[0.01,0.04]$} & 0.00 & {$[0.00,0.01]$} \\
\hline Difference between high and low & $0.02 *$ & {$[0.00,0.04]$} & $0.01 *$ & {$[0.00,0.03]$} \\
\hline
\end{tabular}

Note: Unstandardized path coefficients $\left.p<0.05^{(*}\right), p<0.01\left(^{* *}\right), p<0.001\left(^{(* *}\right)$; DHRM is digital HRM practices.

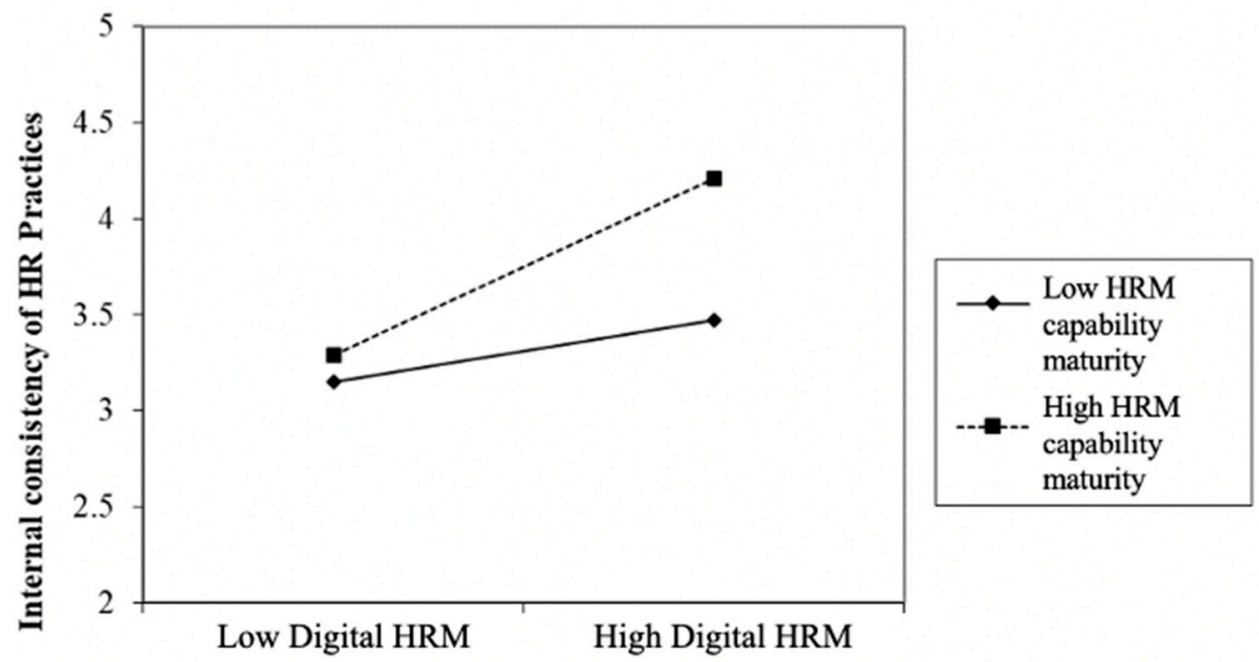

Figure 3. Interaction effect between digital HRM and HRM system maturity on internal consistency of HR Practices.

Hypothesis 4 proposed that HRM capability maturity moderates the indirect relationship between the digital HRM practices and HRM system strength via the internal consistency of HR practices. As demonstrated in Table 4, the indirect effect of digital HRM on HRM system strength via the internal consistency of HR practices was significant when HRM capability maturity was high $(\beta=0.02, p<0.05,95 \% \mathrm{CI}=[0.01,0.03])$; the indirect effect of digital HRM on HRM system strength via internal consistency of HR practices was significant when HRM capability maturity was low $(\beta=0.00$, n.s., $95 \% \mathrm{CI}=[0.00,0.01])$. The difference between these indirect effects was also significant (diff $=0.01, p<0.05$, $95 \% \mathrm{CI}=[0.00,0.03])$, thus supporting Hypothesis 4 .

\section{Discussion}

To date, no consistent conclusion about the effectiveness of digital HRM practices implementation has been drawn. The aim of this study was to understand when and why digital HRM practices lead to HRM system strength. Based on AST theory, the study examined the impact of the interaction between digital HRM practices and HRM capability maturity on HRM system strength and further tested the mediating roles of the internal consistency of HR practices and external social networking. The study's regression results indicated that all of the study's hypotheses were supported.

\subsection{Theoretical Implications}

Our research makes several important theoretical contributions.

First, this study clarified the boundary conditions of the effectiveness of digital HRM implementation by examining the interaction effect between digital HRM practice and 
HRM capability maturity on HRM system strength. Scholars have long debated the impact of digital HRM [27].

Scholars have suggested many positive impacts of digital HRM: saving time and reducing costs $[60,69,70]$, optimizing managerial decisions [71], and promoting organizational innovation [72]. However, several other studies have highlighted negative effects, such as enhancing bias and discrimination [58]. Based on the inconsistent findings of the existing studies, scholars have paid attention to the challenges and requirements to effectively implement digital HRM. For example, some scholars have summarized that analytic skills, manager support, and human resource information technology impact the relationship between HR analytics adoption and organizational outcomes [27]. Additionally, some scholars have listed four main reasons why digital HRM is still in its infancy: maturity, mindset, organization, and competencies. Maturity and mindset focus on a lack of proper data and a lack of strategic thinking issues, respectively. Scholars have also emphasized the importance of assembling a team with a range of competencies, such as excellent statistics skills [73]. Despite all the solutions proposed, we still lack a clear and comprehensive understanding of the institutional basis of an organization's digital HRM. By introducing HRM capability maturity, this study highlighted that the maturity of managing and developing employee competencies is critical to the effectiveness of digital HRM practices. Furthermore, we have enriched the literature in the field of People Capability Maturity. To date, a limited number of studies have focused on a People Capability Maturity Model [74,75], and there are very few empirical studies on HRM capability maturity. This study also enriches the literature in the area of HRM capability maturity.

Second, the study enriched the theoretical perspective of digital HRM-related research using AST theory. Although AST theory asserts that social structures are determined by the technology features and by the spirit underlying the advanced technology's influence on employees' behavior, and that the effectiveness of advanced technology depends on the interaction between technology structures and intra-organizational environment [21], HRM researchers have not yet fully explored the connotations of this theory [31]. However, our study has further validated AST theory in the realm of digital HRM.

Third, by introducing the mediating effects of the internal consistency of HR practices and external social networking with line managers, the study has contributed to the literature on the digital HRM practice-implementation process. Incorporating AST theory, we identified digital HRM technology features, such as immediate interaction, and identified spirit factors, such as advocating seamless communication and collaboration. Both structural factors can act as mediators to achieve digital HRM effectiveness. This study also found that digital HRM promoted internal consistency in HR practices and in social networking with line managers. Our study has also theorized the mediating relationship between digital HRM implementation and effectiveness.

Fourth, we have enriched the digital HRM literature by simultaneously including in the research framework relationships within the HR department, the relationship between the HR department and line managers, and the relationship between employees and the HRM department. The implementation of HRM practices involves multiple actors, including the HR department, line managers, and other employees, and the relationships among these actors affect the effectiveness of digital HRM implementation. Previous research on the impact of digital HRM implementation focused on the relationship between the HR department and employees, exploring HRM roles [25], for example. Yet, the relationship between the HR managers and line managers in the organization and the relationship within the HR department itself, and the resulting impact on digital HRM practices, was yet to be fully explored.

Fifth, this study expanded the literature of digital HRM outcomes by focusing on HRM system strength. The consequences of digital HRM implementation have been a key issue in research. Previous studies have focused on the impact on three levels: organization, employee, and HRM department. The majority of previous studies have explored the impact of digital HRM on organizations, including the effects on cost reduction and organizational 
performance [76]. In terms of individual-level results, e-HRM adoption influenced their trust in the HR department [77] and satisfaction [37]. Existing studies exploring the impact of digital HRM on HR departments focus on variables such as facilitated professionalization of HR departments [35] and improved quality of HR services [31]. However, only when HRM practices are effectively implemented (high strength) can they have a positive effect on employees, allowing them to perceive the effects of corporate HRM practices and change their behavior. Furthermore, extant research has not focused on the impact of digital HRM on the HRM system strength. Through this study's survey and analysis, digital HRM was found to influence the consistency, consensus, and distinctiveness of HR policies positively, thus increasing HRM effectiveness. Our study expanded the focus on the outcomes of digital HRM to include employees' perceptions of HRM effectiveness, which can further influence the employees' attitudes and organizational behaviors. This result echoes Obeidat's (2016) call to explore further the impacts of digital HRM on HRM departments [78]. In addition, research on HRM system strength has focused on the outcomes of its effects. For example, existing studies suggest that HRM system strength has a significant impact on employees' work attitudes and behaviors [79,80] and affects organizational performance [81]. There are few studies that examine the antecedents affecting HRM system strength. Our study thus expands the literature on the area of HRM system strength.

\subsection{Practice Implications}

Although existing research has suggested that digital HRM benefits employees and organizations, our study has suggested that practitioners must be aware of the important impact of HRM capability maturity on successful digital HRM implementation. This is because the digital HRM and HRM capability maturity can influence each other in predicting HRM system strength. When HRM capability maturity is high, digital HRM is more likely to exert a positive impact (improving the internal consistency of HR practices and external social networking with line managers, thereby promoting HRM system strength); when HRM capability maturity is low, the effectiveness of digital HRM implementation is inhibited.

Therefore, to enable the effectiveness of digital HRM fully, organizations should improve HRM capability into the process of implementing digital HRM. Specifically, building a workforce with the capabilities to support strategic business; quantifying employee capabilities; and building processes to perform tasks based on employee capabilities. For capabilities in standardized HRM practices and integrated HRM processes, framing business questions, building hypotheses, gathering data, conducting analyses, revealing insights, determining recommendations, getting your points across, implementation, and evaluation can be used as eight standard steps [82]. Additionally, a competitive advantage analysis and enterprise analysis can be conducted prior to the implementation of digital HRM, as well as an HR process analysis and integrated HR analysis, which can be run during the implementation of digital HRM $[9,83]$ to help build a workforce that supports strategic business. Organizations could reference and build on these findings to raise their HRM maturity levels. Only under the guidance of HRM capability maturity can HR practice bundles achieve internal coordination and better meet the requirements of, and enhance relationships with, other departments. Together, these conditions contribute to HRM system strength.

\subsection{Limitations and Future Directions}

Although our study has made important contributions to the digital HRM literature, we acknowledge the limitations that remain. First, the surveys in our study were all answered by HR managers, allowing for the possibility that the data may suffer from common method bias. However, as our data were collected from 1770 organizations, bias was reduced to some extent. The survey's credibility was also significantly enhanced by all HR managers completing the questionnaire directly online, ensuring anonymity and confidentiality. Nonetheless, we encourage future research to validate and extend our 
results by collecting data from multiple sources or designing multilevel studies to refine this study. For example, future studies could use objective data (e.g., objective organizational performance) to represent the effectiveness of HRM.

Second, in this study we focused on HRM capability maturity as the moderator of the successful implementation of digital HRM. In fact, the effectiveness of digital HRM may be influenced by other conditioners. For example, leadership support and employees' analytic capabilities may also influence the successful implementation of digital HRM [27]. Scholars have proposed a data-enterprise-leadership-targets-analysts (DELTA) model and a logic-analytics-measures-process (LAMP) framework to identify the determinants of HR analytics implementation effectiveness $[84,85]$. Therefore, we encourage future researchers to explore other determinants that influence the successful implementation of digital HRM.

The third limitation of our study is that the data were collected at one time point. Considering the full play of the effects of digital HRM practices may require data from an extended time period [86,87]; a cross-sectional approach may restrict the understanding of changes over time. We suggest that future research utilize longitudinal methods to examine the process of implementing digital HRM practices.

\section{Conclusions}

Based on AST theory, the study found that the positive impact of digital HRM practices on HRM system strength depended on the maturity of HRM capability. Integrating the mediating and boundary conditions of digital HRM in this study, we hope to inspire current and future research that extends progress in the field of digital HRM practices.

Author Contributions: L.W. was mainly responsible for research design, article writing, modification and polishing of this paper; Y.Z. was in charge of the work involving the topic selection, data collection, and content modification of the paper-in particular, he guided us in terms of polishing from beginning to end; G.Z. was mainly responsible for data analysis, article writing, and related auxiliary work. All authors have read and agreed to the published version of the manuscript.

Funding: This research was funded by the National Natural Science Foundation of China, grant number 72072180 .

Institutional Review Board Statement: Ethical review and approval were waived for this study due to Research Ethics Committees such as Institutional Review Board (IRB) are not available in the institution with which the authors of this study are affiliated. It is noted that they strictly followed the APA requirements regarding the treatment and protection of human participants while conducting the study.

Informed Consent Statement: Informed consent was obtained from all subjects involved in the study.

Data Availability Statement: The datasets used and/or analyzed during the current study are available from the corresponding author on reasonable request. Please contact author for data requests.

Conflicts of Interest: The authors declare no conflict of interest.

\section{References}

1. Zhou, Y.; Liu, G.; Chang, X.; Wang, L. The impact of HRM digitalization on firm performance: Investigating three-way interactions. Asia Pac. J. Hum. Resour. 2021, 59, 20-43. [CrossRef]

2. Beisen. Available online: https://news.alphalio.cn/PDF/2021\%E4\%B8\%AD \%E5\%9B\%BD $\%$ E4\%BA\%BA $\%$ E5\%8A $\% 9 B \% E 8 \% B 5$ $\% 84 \%$ E6 \%BA $\% 90 \%$ E7\%AE $\% A 1 \% E 7 \% 90 \% 86 \%$ E5\%B9\%B4\%E5\%BA $\%$ A6\%E8\%A7\%82\%E5\%AF\%9F-\%E5\%8C $\% 97 \%$ E6 $\% 3$ \%AE-2021.1-49\%E9\%A1\%B5.pdf (accessed on 14 December 2021).

3. Accenture. Available online: https://www.accenture.com/_acnmedia/PDF-120/Accenture-TechVision-2020-Exec-SummaryReport-2.pdf (accessed on 14 December 2021).

4. Minbaeva, D.B. Building credible human capital analytics for organizational competitive advantage. Hum. Resour. Manag. 2018, 57, 701-713. [CrossRef]

5. Gal, U.; Jensen, T.B.; Stein, M.-K. Breaking the vicious cycle of algorithmic management: A virtue ethics approach to people analytics. Inf. Organ. 2020, 30, 100301. [CrossRef]

6. van Esch, P.; Black, J.S.; Ferolie, J. Marketing AI recruitment: The next phase in job application and selection. Comput. Hum. Behav. 2019, 90, 215-222. [CrossRef] 
7. Pace, D. Commentary on Radical HRM innovation and competitive advantage: The Moneyball story-Moneyball lessons: The transition from HR intuition to HR analytics. Hum. Resour. Manag. 2006, 45, 140-142.

8. Lawler, E.E., III; Levenson, A.; Boudreau, J.W. HR metrics and analytics: Use and impact. Hum. Resour. Manag. 2004, $27,27-36$.

9. Levenson, A. Using workforce analytics to improve strategy execution. Hum. Resour. Manag. 2018, 57, 685-700. [CrossRef]

10. Schiemann, W.A.; Seibert, J.H.; Blankenship, M.H. Putting human capital analytics to work: Predicting and driving business success. Hum. Resour. Manag. 2018, 57, 795-807. [CrossRef]

11. Aral, S.; Brynjolfsson, E.; Wu, L. Three-Way Complementarities: Performance Pay, Human Resource Analytics, and Information Technology. Manag. Sci. 2012, 58, 913-931. [CrossRef]

12. Malik, A.; Budhwar, P.; Patel, C.; Srikanth, N.R. May the bots be with you! Delivering HR cost-effectiveness and individualized employee experiences in an MNE. Int. J. Hum. Resour. Manag. 2021. [CrossRef]

13. Brynjolfsson, E.; Hitt, L. Paradox lost? Firm-level evidence on the returns to information systems spending. Manag. Sci. 1996, 42, 541-558. [CrossRef]

14. Angrave, D.; Charlwood, A.; Kirkpatrick, I.; Lawrence, M.; Stuart, M. HR and analytics: Why HR is set to fail the big data challenge. Hum. Resour. Manag. J. 2016, 26, 1-11. [CrossRef]

15. Minbaeva, D. Human capital analytics: Why aren't we there? Introduction to the special issue. J. Organ. Eff. 2017, 4, 110-118. [CrossRef]

16. Chapman, D.S.; Webster, J. The use of technologies in the recruiting, screening, and selection processes for job candidates. Int. J. Sel. Assess. 2003, 11, 113-120. [CrossRef]

17. Reddick, C.G. Human resources information systems in Texas city governments: Scope and perception of its effectiveness. Public Pers. Manag. 2009, 38, 19-34. [CrossRef]

18. Trullen, J.; Bos-Nehles, A.; Valverde, M. From intended to actual and beyond: A cross-disciplinary view of (human resource management) implementation. Int. J. Manag. Rev. 2020, 22, 150-176. [CrossRef]

19. Bowen, D.E.; Ostroff, C. Understanding HRM-firm performance linkages: The role of the "strength" of the HRM system. Acad. Manag. Rev. 2004, 29, 203-221.

20. Shin, D.; Konrad, A.M. Causality between high-performance work systems and organizational performance. J. Manag. 2017, 43, 973-997. [CrossRef]

21. DeSanctis, G.; Poole, M.S. Capturing the complexity in advanced technology use: Adaptive structuration theory. Organ. Sci. 1994, 5, 121-147. [CrossRef]

22. Bondarouk, T.; Harms, R.; Lepak, D. Does e-HRM lead to better HRM service? Int. J. Hum. Resour. Manag. 2017, $28,1332-1362$. [CrossRef]

23. Kehoe, R.R.; Han, J.H. An expanded conceptualization of line managers' involvement in human resource management. J. Appl. Psychol. 2020, 105, 111-129. [CrossRef]

24. Pak, J.; Kim, S. Team manager's implementation, high performance work systems intensity, and performance: A multilevel investigation. J. Manag. 2018, 44, 2690-2715. [CrossRef]

25. Panos, S.; Bellou, V. Maximizing e-HRM outcomes: A moderated mediation path. Manag. Decis. 2016, 54, 1088-1109. [CrossRef]

26. Kryscynski, D.; Reeves, C.; Stice-Lusvardi, R.; Ulrich, M.; Russell, G. Analytical abilities and the performance of HR professionals. Hum. Resour. Manag. 2018, 57, 715-738. [CrossRef]

27. Marler, J.H.; Boudreau, J.W. An evidence-based review of HR Analytics. Int. J. Hum. Resour. Manag. 2017, 28, 3-26. [CrossRef]

28. Hamilton, R.H.; Sodeman, W.A. The questions we ask: Opportunities and challenges for using big data analytics to strategically manage human capital resources. Bus. Horiz. 2020, 63, 85-95. [CrossRef]

29. Curtis, B.; Hefley, B.; Miller, S. People Capability Maturity Model (P-CMM), version 2.0; Software Engineering Institute, CarnegieMellon University: Pittsburgh, PA, USA, 2009.

30. Hannon, J.; Jelf, G.; Brandes, D. Human resource information systems: Operational issues and strategic considerations in a global environment. Int. J. Hum. Resour. Manag. 1996, 7, 245-269. [CrossRef]

31. Bondarouk, T.; Parry, E.; Furtmueller, E. Electronic HRM: Four decades of research on adoption and consequences. Int. J. Hum. Resour. Manag. 2017, 2, 98-131. [CrossRef]

32. Colquitt, J.A.; Zapata-Phelan, C.P. Trends in theory building and theory testing: A five-decade study of the Academy of Management Journal. Acad. Manag. J. 2007, 50, 1281-1303. [CrossRef]

33. Quaosar, G.A.A.; Hoque, M.R.; Bao, Y. Investigation on the precursors to and effects of human resource information system use: The case of a developing country. Cogent Bus. Manag. 2018, 5, 1485131. [CrossRef]

34. Ramayah, T.; Kurnia, S. Antecedents and outcomes of human resource information system (HRIS) use. Int. J. Product. Perform. Manag. 2012, 6, 603-623.

35. Gardner, S.D.; Lepak, D.P.; Bartol, K.M. Virtual HR: The impact of information technology on the human resource professional. J. Vocat. Behav. 2003, 63, 159-179. [CrossRef]

36. Wahyudi, E.; Park, S.M. Unveiling the value creation process of electronic human resource management: An Indonesian case. Public Pers. Manag. 2014, 43, 83-117. [CrossRef]

37. Lukaszewski, K.M.; Stone, D.L.; Stone-Romero, E.F. The effects of the ability to choose the type of human resources system on perceptions of invasion of privacy and system satisfaction. J. Bus. Psychol. 2008, 23, 73. [CrossRef] 
38. Cronin, B.; Morath, R.; Curtin, P.; Heil, M. Public sector use of technology in managing human resources. Hum. Resour. Dev. Rev. 2006, 16, 416-430. [CrossRef]

39. John, S.; Björkman, I. In the eyes of the beholder: The HRM capabilities of the HR function as perceived by managers and professionals. Hum. Resour. Manag. J. 2015, 25, 424-442. [CrossRef]

40. Parry, E. An examination of e-HRM as a means to increase the value of the HR function. Int. J. Hum. Resour. Manag. 2011, 22, 1146-1162. [CrossRef]

41. Voermans, M.; van Veldhoven, M. Attitude towards E-HRM: An empirical study at Philips. Pers. Rev. 2007, 36, 887-902. [CrossRef]

42. Haines, V.Y.; Lafleur, G. Information technology usage and human resource roles and effectiveness. Hum. Resour. Manag. 2008, 47, 525-540. [CrossRef]

43. Ruël, H.; Van der Kaap, H. E-HRM usage and value creation. Does a facilitating context matter? Ger. J. Hum. Resour. Manag. 2012, 26, 260-281. [CrossRef]

44. Alam, M.G.R.; Masum, A.K.M.; Beh, L.-S.; Hong, C.S. Critical factors influencing decision to adopt human resource information system (HRIS) in hospitals. PLoS ONE 2016, 11, 1-22. [CrossRef]

45. Hustad, E.; Munkvold, B.E. IT-supported competence management: A case study at Ericsson. Inf. Syst. Manag. 2005, 22, 78-88. [CrossRef]

46. Masum, A.K.M.; Alam, M.G.R.; Alam, M.S.; Azad, M.A.K. Adopting factors of electronic human resource management: Evidence from Bangladesh. In Proceedings of the International Conference on Innovations in Science, Engineering and Technology (ICISET), International Islamic University Chittagong, Chittagong, Bangladesh, 28-29 October 2016.

47. Rahman, M.A.; Qi, X.; Jinnah, M.S. Factors affecting the adoption of HRIS by the Bangladeshi banking and financial sector. Cogent Bus. Manag. 2016, 3, 1262107. [CrossRef]

48. Quaosar, G.M.A.A. Determinants of the Adoption of Human Resources Information Systems in a Developing Country: An Empirical Study. Int. Technol. Manag. Rev. 2017, 6, 82-93. [CrossRef]

49. Cascio, W.; Boudreau, J. Investing in People: Financial Impact of Human Resource Initiatives; FT Press: Upper Saddle River, NJ, USA, 2010.

50. Kellogg, K.C.; Valentine, M.A.; Christin, A. Algorithms at work: The new contested terrain of control. Acad. Manag. Ann. 2020, 14, 366-410. [CrossRef]

51. Cooke, F.L. Modeling an HR shared services center: Experience of an MNC in the United Kingdom. Hum. Resour. Manag. 2006, 45, 211-227. [CrossRef]

52. Jia, Q.; Guo, Y.; Li, R.; Li, Y.; Chen, Y. A conceptual artificial intelligence application framework in human resource management. In Proceedings of the 18th International Conference on Electronic Business, Guilin, China, 2-6 December 2018.

53. Strohmeier, S.; Piazza, F. Artificial intelligence techniques in human resource management-A conceptual exploration. In Intelligent Techniques in Engineering Management; Springer: Berlin/Heidelberg, Germany, 2015; pp. 149-172.

54. Martin, G.; Reddington, M. Theorizing the links between e-HR and strategic HRM: A model, case illustration and reflections. Int . J. Hum. Resour. Manag. 2010, 21, 1553-1574. [CrossRef]

55. Strohmeier, S. Research in e-HRM: Review and implications. Hum. Resour. Manag. Rev. 2007, 17, 19-37. [CrossRef]

56. Wright, P.M.; McMahan, G.C. Theoretical perspectives for strategic human resource management. J. Manag. 1992, 18, 295-320. [CrossRef]

57. Kehoe, R.R.; Collins, C.J. Human resource management and unit performance in knowledge-intensive work. J. Appl. Psychol. 2017, 102, 1222-1236. [CrossRef]

58. Tambe, P.; Cappelli, P.; Yakubovich, V. Artificial intelligence in human resources management: Challenges and a path forward. Calif. Manag. Rev. 2019, 61, 15-42. [CrossRef]

59. Haines, V.Y.; Petit, A. Conditions for successful human resource information systems. Hum. Resour. Manag. 1997, 36, 261-275. [CrossRef]

60. Ruël, H.; Bondarouk, T.; Looise, J.K. E-HRM: Innovation or irritation. An explorative empirical study in five large companies on web-based HRM. Manag. Rev. 2004, 15, 364-380. [CrossRef]

61. Lepak, D.P.; Liao, H.; Chung, Y.; Harden, E.E. A conceptual review of human resource management systems in strategic human resource management research. Res. Pers. Hum. Resour. Manag. 2006, 25, 217-271.

62. Minbaeva, D.; Pedersen, T.; Björkman, I.; Fey, C.F.; Park, H.J. MNC knowledge transfer, subsidiary absorptive capacity, and HRM. J. Int. Bus. Stud. 2003, 34, 586-599. [CrossRef]

63. Delery, J.; Gupta, N. Human resource management practices and organizational effectiveness: Internal fit matters. J. Organ. Eff. 2016, 3, 139-163. [CrossRef]

64. Patel, P.C.; Messersmith, J.G.; Lepak, D.P. Walking the tightrope: An assessment of the relationship between high-performance work systems and organizational ambidexterity. Acad. Manag. J. 2013, 56, 1420-1442. [CrossRef]

65. Kim, S.; Su, Z.X.; Wright, P.M. The "HR-line-connecting HRM system" and its effects on employee turnover. Hum. Resour. Manag. 2018, 57, 1219-1231. [CrossRef]

66. Hauff, S.; Alewell, D.; Katrin Hansen, N. HRM system strength and HRM target achievement-Toward a broader understanding of HRM processes. Hum. Resour. Manag. 2017, 56, 715-729. [CrossRef]

67. Brislin, R.W. Back-translation for cross-cultural research. J. Cross-Cult. Psychol. 1970, 1, 185-216. [CrossRef]

68. Hair, J.F.; Black, W.C.; Babin, B.J.; Anderson, R.E.; Tatham, R.L. Multivariate Data Analysis; Prentice Hall College Div.: Upper Saddle River, NJ, USA, 1998; Volume 5. 
69. Buckley, P.; Minette, K.; Joy, D.; Michaels, J. The use of an automated employment recruiting and screening system for temporary professional employees: A case study. Hum. Resour. Manag. J. 2004, 43, 233-241. [CrossRef]

70. Oiry, E. Electronic Human Resource Management: Organizational Responses to Role Conflicts Created by E-Learning. Int. J. Dev. Biol. 2010, 13, 111-123. [CrossRef]

71. Beulen, E. The contribution of a global service provider's Human Resources Information System (HRIS) to staff retention in emerging markets: Comparing issues and implications in six developing countries. Inf. Technol. People 2009, 22, 270-288. [CrossRef]

72. Lin, L.-H. Electronic human resource management and organizational innovation: The roles of information technology and virtual organizational structure. Int. J. Hum. Resour. Manag. 2011, 22, 235-257. [CrossRef]

73. Andersen, M.K. Human capital analytics: The winding road. J. Organ. Eff. 2017, 4, 133-136. [CrossRef]

74. Chen, Y.-C.; Wang, Y.-J. Application and development of the people capability maturity model level of an organisation. Total Qual. Manag. Bus. Excell. 2018, 29, 329-345. [CrossRef]

75. Zare, M.S.; Tahmasebi, R.; Yazdani, H. Maturity assessment of HRM processes based on HR process survey tool: A case study. Bus. Process Manag. J. 2018, 24, 610-634. [CrossRef]

76. Ali, E.; Younas, M.; Saeed, T. Impact of Moderating Role of e-Administration on Training, Perfromance Appraisal and Organizational Performance. Int. J. Econ. Manag. 2017, 10, 3764-3770.

77. Bissola, R.; Imperatori, B. The unexpected side of relational e-HRM: Developing trust in the HR department. Empl. Relat. 2014, 36, 376-397. [CrossRef]

78. Obeidat, S.M. The link between e-HRM use and HRM effectiveness: An empirical study. Pers. Rev. 2016, 45, 1281-1301. [CrossRef]

79. Chen, S.-J.; Lin, P.-F.; Lu, C.-M.; Tsao, C.-W. The moderation effect of HR strength on the relationship between employee commitment and job performance. Soc. Behav. Personal. Int. J. 2007, 35, 1121-1138. [CrossRef]

80. Frenkel, S.J.; Li, M.; Restubog, S.L.D. Management, organizational justice and emotional exhaustion among Chinese migrant workers: Evidence from two manufacturing firms. Br. J. Ind. Relat. 2012, 50, 121-147. [CrossRef]

81. Sels, L.; De Winne, S.; Maes, J.; Delmotte, J.; Faems, D.; Forrier, A. Unravelling the HRM-Performance link: Value-creating and cost-increasing effects of small business HRM. J. Manag. Stud. 2006, 43, 319-342. [CrossRef]

82. Guenole, N.; Ferrar, J.; Feinzig, S. The Power of People: Learn How Successful Organizations Use Workforce Analytics to Improve Business Performance; FT Press: Hoboken, NJ, USA, 2017.

83. Mondore, S.; Douthitt, S.; Carson, M. Maximizing the impact and effectiveness of HR analytics to drive business outcomes. People Strategy 2011, 34, 20-27.

84. Boudreau, J.; Cascio, W. Human capital analytics: Why are we not there? J. Organ. Eff. 2017, 4, 119-126. [CrossRef]

85. Davenport, T.H.; Harris, J.; Shapiro, J. Competing on Talent Analytics. Harv. Bus. Rev. 2010, 88, 1-6.

86. Hanif, F. Impact of Human Resource Information System (HRIS): Substituting or Enhancing HR Function. Available online: https:/ / papers.ssrn.com/sol3/papers.cfm?abstract_id=1425905 (accessed on 19 January 2011).

87. Lego, J. Creating a business case for your organization's web-based HR initiative. In Web-Based Human Resources; AJ Walker, R.M., Ed.; McGraw-Hill: New York City, NY, USA, 2001; pp. 131-149. 